\title{
PENGARUH ELECTRONIC WORD OF MOUTH MELALUI INSTAGRAM TERHADAP KEPUTUSAN PEMBELIAN PADA KAFE DI KOTA PEKANBARU
}

\author{
Amie Dhiza $^{1}$, Zulkarnain $^{2}$, Any Widiyatsari ${ }^{3}$ \\ ${ }^{1)}$ Mahasiswa Program Pascasarjana Universitas Riau \\ 2),3) Dosen Program Pascasarjana Universitas Riau \\ Email : amiedhizayusmardi@gmail.com ${ }^{1}$
}

\begin{abstract}
The purpose of this study is to examine and analyze the effect of intensity on purchasing decisions. To analyze the effect of content on purchasing decisions. To analyze the effect of positive valency on purchasing decisions. To analyze the effect of negative valency on purchasing decisions. The population in this study are visitors of the cafes that are the object of research in the city of Pekanbaru, especially for cafes that are not on the pratocol road. The sample in this study were 110 people. The sample method uses the area sampling method. The data used in this study are primary and secondary data, while data collection techniques are using questionnaires. The data analysis technique used in this study is multiple linear regression. Research findings indicate that intensity has a positive and significant effect on purchasing decisions. Content has a positive and significant effect on purchasing decisions. Valency positive has a positive and significant effect on purchasing decisions. This means that more and more positive comments from consumers on the service and food and drinks served at a cafe, will increase consumer purchasing decisions at the cafe even to people who have never been to the cafe. Valency negative and significant negative effect on purchasing decisions. This means that the more negative comments or complaints of consumers over services and food and drinks served at a cafe, the consumer's purchasing decisions at the cafe will decrease.
\end{abstract}

Keywords: Intensity, Content, Positive Valency, Negative Valency and Purchasing Decisions 


\section{PENDAhUluAN}

Fenomena saat ini, perkembangan bisnis produk dan jasa di Indonesia terutama di Kota Pekanbaru berkembang cukup pesat. Salah satu yang berkembang pesat pada saat ini adalah usaha kuliner, hal ini bisa dilihat dari semakin banyaknya usaha jasa dibidang kuliner yang terus bermunculan di Pekanbaru. Salah satunya sudah banyak kafe-kafe bermunculan dikarenakan mulainya anak muda yang mengembangkan kreatifitasnya ke jalur bisnis apalagi di bidang kuliner. Bisnis kafe merupakan salah satu opsi untuk memasuki peluang bisnis tersebut. Salah satunya bersantai di kafe kini sedang banyak diminati dan juga sertai gaya hidup masyarakat perkotaan yang menganggap kafe sebagai tempat bergaul. Untuk mencari minat pengunjung kafe dan memberikan kesan dan pesan yang baik untuk konsumen, selain menu makanan, keberadaan tempat, pelayanan, dan harga yang terjangkau di semua kalangan ekonomi rendah atau tinggi.

Persaingan kafe sangatlah ketat, hal ini dikarenakan oleh semakin banyaknya konsumen kafe yang dapat dilihat dari jumlah penduduk Kota Pekanbaru maupun penduduk luar kota yang masuk dan menetap di Kota Pekanbaru. Dengan banyaknya jumlah penduduk bisa mempengaruhi banyaknya pangsa pasar (market share) yang terus meningkat dan semakin kuatnya pandangan bahwa usaha kuliner merupakan bisnis yang menjanjikan.

Pertumbuhan jumlah usaha kafe di Pekanbaru yang terus mengalami peningkatan menunjukkan bahwa tingkat persaingan dalam sektor bisnis tersebut juga semakin meningkat ketat. Hal ini dapat dilihat dari jumlah kafe yang semakin meningkat setiap tahunnya. Berdasarkan data dari Badan Pendapatan Daerah Kota Pekanbaru, maka terdapat 157 kafe yang ada di Kota Pekanbaru (Bapenda Kota Pekanbaru 2018). Banyaknya kafe yang ada di kota ini tentu saja menjadikan banyak alternatif bagi masyarakat. Oleh karena itu, kafe yang mampu bertahan dalam industri kuliner adalah kafe yang selalu mampu untuk menarik konsumen berkunjung. Kafe-kafe tersebut dituntut untuk memiliki berbagai strategi yang dapat meningkatkan kunjungan konsumen serta meningkatkan keinginan konsumen untuk membeli produk kafe tersebut.

Cara untuk memenangkan persaingan adalah dengan membuat sesuatu yang berbeda. Perbedaan diperlukan karena setiap bisnis pasti didapati produk yang serupa dengan harga yang berkisar beda tipis bahkan sama, selain itu menggencarkan promosi juga perlu dilakukan untuk menarik perhatian lebih para konsumen. Dengan begitu, pelaku usaha harus memperhatikan keputusan pembelian konsumen. Sehingga konsumen dapat memilih kafe mana yang menarik untuk dikunjungi dan bukan hanya sebatas berkunjung tetapi memutuskan pembelian, kemungkinan membeli dengan jumlah yang banyak atau sedikit.

Berkaitan dari hal tersebut
peneliti merasa tertarik ingin
melakukan wawancara dan
berdasarkan hasil wawancara dengan
manajemen kafe, yang mana mereka
mengatakan rata-rata jumlah


pengunjung disetiap bulan bersifat fluktuatif dan terlihat juga bahwa di tahun 2017 sampai dengan tahun 2018 mengalami penurunan jumlah rata-rata pengunjung atau konsumen. Ini membuktikan bahwa konsumen yang memutuskan pembelian tidak menetap dan bervariatif mulai dari pembelian makanan dan minuman. Hal ini menunjukkan adanya permasalah keputusan pembelian pada di kafe terutama jika kafe-kafe tersebut terletak tidak di jalan-jalan protokol atau jalan utama yang ada di Kota Pekanbaru, sehingga konsumen akan kesulitan untuk menemukan kafe tersebut. Penurunan jumlah pengunjung ini tentu akan mempengaruhi jumlah penjualan. Berikut ini merupakan data persentase penjualan bersih bulanan pada tahun 2017 sampai dengan tahun 2018.

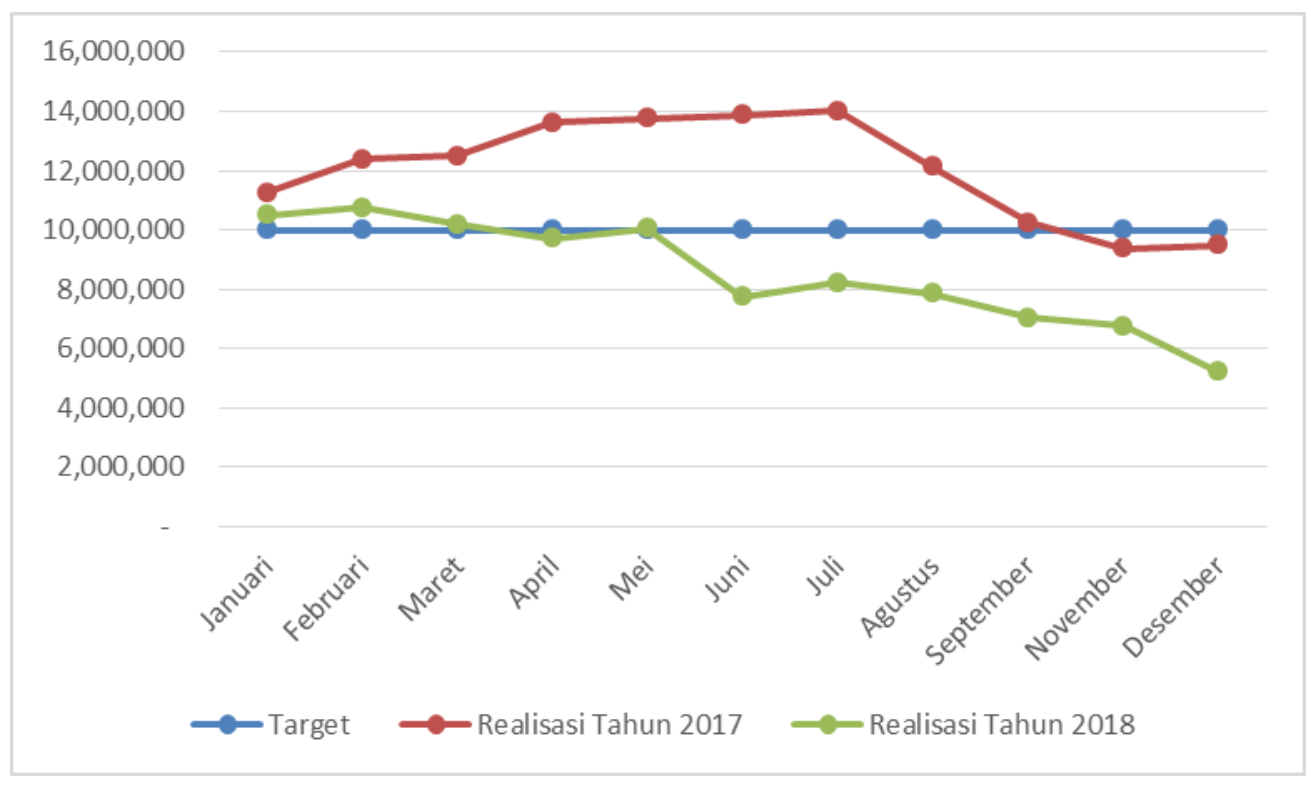

Gambar 1 Persentase Penjualan Kafe 2017-2018

Sumber: Data Internal, 2019

Berdasarkan Gambar 1 di atas, maka dapat dilihat data persentase penjualan diketahui bahwa, selama dua tahun ini kafe cenderung mengalami perubahan fluktuatif dan menurun. Setelah peneliti melakukan wawancara dengan pihak manajemen kafe diketahui bahwa kafe memiliki target penjualan minimal sebesar Rp. 10.000.000,00 per bulan. Pada tahun 2017 penjualan pada bulan Januari sampai September kenaikan penjualan mencapai target yang signifikan, tetapi terjadi penurunan pada pada tahun 2018 yakni pada bulan juni sampai dengan bulan Desember tidak mencapai target minimalnya.

Strategi yang bisa dilakukan dalam rangka meningkatkan keputusan pembelian konsumen adalah dengan memberikan informasi tentang produk makanan dan minuman yang ditawarkan oleh kafe-kafe tersebut kepada konsumen karena informasi sangat berperan 
penting dalam menentukan keputusan pembelian seorang konsumen. Konsumen akan mencari informasi tentang produk yang dibutuhkan, kemudian mereka akan mengevaluasi produk yang dirasakan paling cocok dan dapat memenuhi kebutuhan konsumen. Langkah selanjutnya konsumen akan memutuskan untuk membeli atau tidak.

Perkembangan eWOM ini ditopang oleh perkembangan teknologi dan tingkat penggunaan media sosial oleh berbagai kalangan, terutama kaum milenial. Berdasarkan pada survey Assosiasi Penyelenggara Jasa Internet Indonesia (2017), maka jumlah pengguna internet untuk media sosial merupakan yang paling banyak, terlihat dari 129.2 juta pengguna internet yang mengakses media sosial. Pada tahun 2017 meningkat menjadi 131.4 juta pengguna internet yang mengakses media sosial.

Instagram merupakan sebuah sarana yang sesuai untuk menerapkan sebuah promosi suatu produk karena mampu menyampaikan informasi secara visual maupun tulisan. Instagram sebagai media sosial dapat membantu pelaksanaan dan penerapan eWOM sebagai salah satu strategi pemasaran menjadi lebih efisien dan lebih cepat. Instagram muncul bukan hanya sebagai sebuah marketing tools, Instagram sendiri dapat dikatakan sebagai generator untuk terjadinya eWOM di media sosial sehingga dapat mempengaruhi keputusan pembelian konsumen.

Instagram merupakan kanvas kreativitas bagi komunitas mobilefirst Indonesia yang muda dan antusias. Orang datang ke Instagram untuk terinpirasi secara visual dan dapat menawarkan solusi iklan yang menciptakan nilai bagi komunitas dan mendorong hasil bisnis yang berdampak bagi bisnis besar maupun bisnis kecil di Indonesia. Dilansir dari tempo.co, pihak Instagram memberi pernyataan secara resmi bahwa pengguna Instagram di Indonesia tahun 2017 telah lebih dari 45 juta jiwa. Awal tahun 2016, pengguna Instagram Indonesia sebanyak 22 juta jiwa. Menurut data tersebut, pengguna Instagram di tahun 2017 jauh mengalami pertambahan yang signifikan dari tahun sebelumnya.

Informasi tentang produk yang disampaikan melalui Instagram ini, maka konsumen bisa mendapatkan informasi tentang produk yang baru di kafe. Karena pada media sosial, konsumen dapat mengulas tanggapan konsumen lain terhadap produk yang ada pada kafekafe tersebut. Selain itu, konsumen juga dapat menyampaikan berbagai keluhan tentang produk, seperti rasa makanan, aroma, tampilan makanan, kebersihan tempat, keramahan pelayanan, serta informasi lainnya. Dengan adanya komunitas Instagram ini, maka diharapkan akan memberikan kontribusi terhadap konsumen yang mencari informasi tentang produk sebelum memutuskan untuk berkunjung dan menikmati makanan serta minuman pada kafekafe tersebut.

Langkah pertama yang perlu dilakukan untuk meningkatkan efektifitas promosi melalui eWOM adalah dengan memperhatikan tingkat intensitas. Intensitas berkaitan dengan frekuensi akses informasi, frekuensi interaksi pengguna jejaring sosial, serta banyaknya ulasan yang ditulis oleh pengguna jejaring sosial. Semakin 
sering seorang konsumen melihat tayangan atau informasi tentang suatu produk, maka keinginan konsumen untuk membeli suatu produk yang ditawarkan kafe juga akan semakin meningkat, begitu juga dengan semakin sering konsumen melihat ulasan positif pada setiap postingan produk pada Instagram, maka akan semakin menarik konsumen untuk mencoba atau membeli produk tersebut.

Langkah selanjutnya yang bisa dilakukan untuk meningkatkan efektifitas eWOM adalah konten. Konten adalah isi informasi dari situs jejaring sosial berkaitan dengan produk dan jasa. Indikator dari konten meliputi informasi tentang variasi produk yang dijual, informasi tentang kualitas produk, informasi tentang harga yang ditawarkan, informasi tentang keamanan transaksi, dan situs jejaring internet yang disediakan.

Langkah lainnya yang bisa meningkatkan efektifitas eWOM melalui Instagram untuk meningkatkan keputusan pembelian adalah valency positive dan valency negative tentang produk yang ada di Instagram. Pendapat konsumen ini penting bagi konsumen lainnya yang ingin berkunjung dan membeli produk kafe, karena konsumen akan membandingkan dari berbagai macam respon atau tanggapan konsumen lain, hingga pada akhirnya konsumen yang melihat komentar positif dan negatif tersebut akan mengambil kesimpulan untuk membeli atau tidak.

Oleh karena itu, setiap Instagram kafe-kafe yang ada di Kota Pekanbaru harus melakukan perbaikan terhadap efektifitas eWOM melalui Instagram. Model bisnis menggunakan Instagram ini pun terjadi akibat beberapa faktor seperti, tingginya tuntutan akan inovasi, produktivitas, cost saving, dan perkembangan intelektualitas yang terjadi pada masyarakat membuat para pelaku usaha harus memutar otak agar bisnisnya dapat mengikuti arus perkembangan yang sedang terjadi. Melalui Instagram, dapat membantu para pelaku usaha untuk dapat lebih efektif dan efisien lagi dalam hal pemasaran produk atau jasanya. Karena, penggunaan media sosial kini telah dapat dikategorikan sebagai salah satu gaya hidup masyarakat Indonesia.

Pengembangan penelitian ini dilakukan terhadap konsumen kafe, yang berlokasi jauh dari jalan-jalan protokol Kota Pekanbaru. Adapun kafe-kafe yang dianggap memiliki kesamaan konsep dan juga lokasi yang jauh dari jalan utama yang ada di Kota Pekanbaru adalah Dijon Coffee Company, Rindu Kopi, Waroeng Kopi Harapan Keluarga, Krema Koffie, Amor Cafeinvape, Forty One Cafe \& Coffee Shop, Suar Coffee, Vivace Cafe, Koktong Setiabudi, Jeber Cafe, Erber Coffee Nodal, Amigos Coffee Friendly. Selain itu juga mereka memiliki keunikan dalam mempromosikan produknya, yaitu dengan menggunakan media Instagram. Alasan penggunaan Instagram tersebut dikarenakan konsumen yang menjadi fokus utamanya adalah berada pada kategori usia 17-28 tahun atau kalangan milenial.

Oleh karena itu, penelitian ini berjudul: Pengaruh Electronic Word Of Mouth Melalui Instagram Terhadap Keputusan Pembelian Pada Kafe Di Kota Pekanbaru. 


\section{II.KERANGKA TEORI}

\section{Keputusan Pembelian}

Menurut Kotler dan Amstrong (2008: 179) keputusan pembelian merupakan hasil dari suatu proses yang terdiri dari lima tahap: pengenalan kebutuhan, pencarian informasi, evaluasi alternatif, keputusan pembelian, dan perilaku pasca pembelian.

Setiadi (2010:

menyatakan bahwa inti dari pengambilan keputusan konsumen (customer decision making) adalah proses pengintegrasian yang mengombinasikan pengetahuan untuk mengevaluasi dua atau lebih perilaku alternatif, dan memilih salah satu diantaranya. Pemasar juga perlu mengetahui apasaja yang menjadi bahan pertimbangan orang dalam keputusan pembelian dan peran apa yang dimainkan masing-masing orang.

Secara umum, keputusan merupakan pemilihan dari dua atau lebih alternatif pilihan. Dengan kata lain untuk membuat keputusan harus terdapat alternatif pilihan. Sebaliknya jika konsumen tidak memiliki alternatif untuk memilih maka tidak dapat dikategorikan sebagai pengambilan keputusan Swastha (2007: 125). Selain itu menurut Hardiawan (2012: 14) pengambilan keputusan merupakan kegiatan individu secara langsung terlibat dalam pengambilan keputusan untuk melakukan pembelian terhadap produk yang akan ditawarkan oleh penjual.

Kotler (2009: 235) menyebutkan tahapan-tahapan proses pengambilan keputusan pembelian, secara umum proses itu dapat dilihat pada gambar sebagai berikut:

\section{Gambar 2: Tahapan Pengambilan Keputusan}

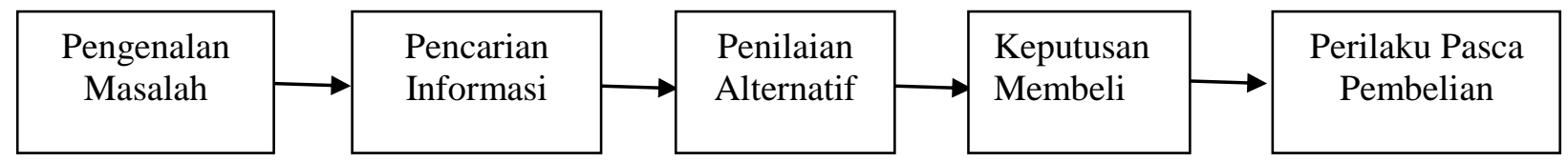

Sumber: Kotler (2009: 235)

Menurut Kotler (2009: 303), menyatakan konsumen yang merasa puas akan memperlihatkan peluang membeli yang lebih tinggi dalam kesempatan berikutnya. Konsumen yang merasa puas akan cenderung mengatakan sesuatu yang serba baik tentang produk yang bersangkutan kepada orang lain. Apabila konsumen dalam melakukan pembelian tidak merasa puas dengan produk yang telah dibelinya ada dua kemungkinan yang akan dilakukan oleh konsumen. Pertama, dengan meninggalkan atau konsumen tidak mau melakukan pembelian ulang. Kedua, ia akan mencari informasi tambahan mengenai produk yang telah dibelinya untuk menguatkan pendiriannya mengapa ia memilih produk itu sehingga ketidakpuasan tersebut dapat dikurangi.

Sementara itu Alma (2009:

104) menyatakan bahwa ada beberapa proses dalam pengambilan keputusan pembeli yaitu: 
Gambar 3: Tahapan Pengambilan Keputusan Alma (2009: 104)

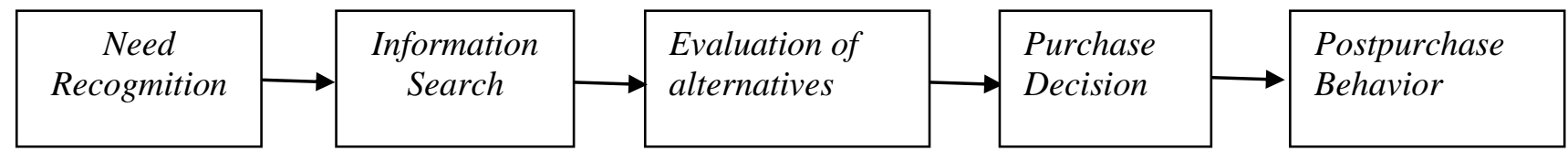

Sumber: Alma (2009: 104)

Perilaku pasca pembelian ini sangat ditentukan oleh pengalaman konsumen dalam mengkonsumsi produk yang ia beli. Apakah ia akan puas atau kecewa, jadi tergantung pada jarak ekspektasi dengan kenyataan yang dihadapi. Jika kenyataanya tidak puas, maka ia akan kecewa. Jika sesuai antara apa yang diharapkan dengan yang dialami, berarti puas, dan jika kenyataannya lebih bagus dari yang diharapkan maka ia akan sangat gembira. Biasanya ekspektasi konsumen makin besar, karena mendengar cerita penjual atau karena komentar teman-temannya tentang produk itu sangat bagus dan apabila tidak benar, maka ia akan sangat kecewa. Oleh sebab itu tidak perlu penjual terlalu berlebihan menyatakan keunggulan produknya, agar jarak antara harapan dan kenyataan yang dialami konsumen tidak terlalu jauh.Sehingga konsumen merasa puas, akhirnya terjalin hubungan yang baik.

Menurut Schiffman dan Kanuk (2008: 8), ada tiga tahap dalam proses pengambilan keputusan yang saling berhubungan satu sama lain: tahap masukan (input), tahap proses, dan tahap keluaran (output). Dapat dilihat pada gambar model sederhana pengambilan keputusan konsumen.

\section{Gambar 4 : Model Sederhana Pengambilan Keputusan Konsumen}

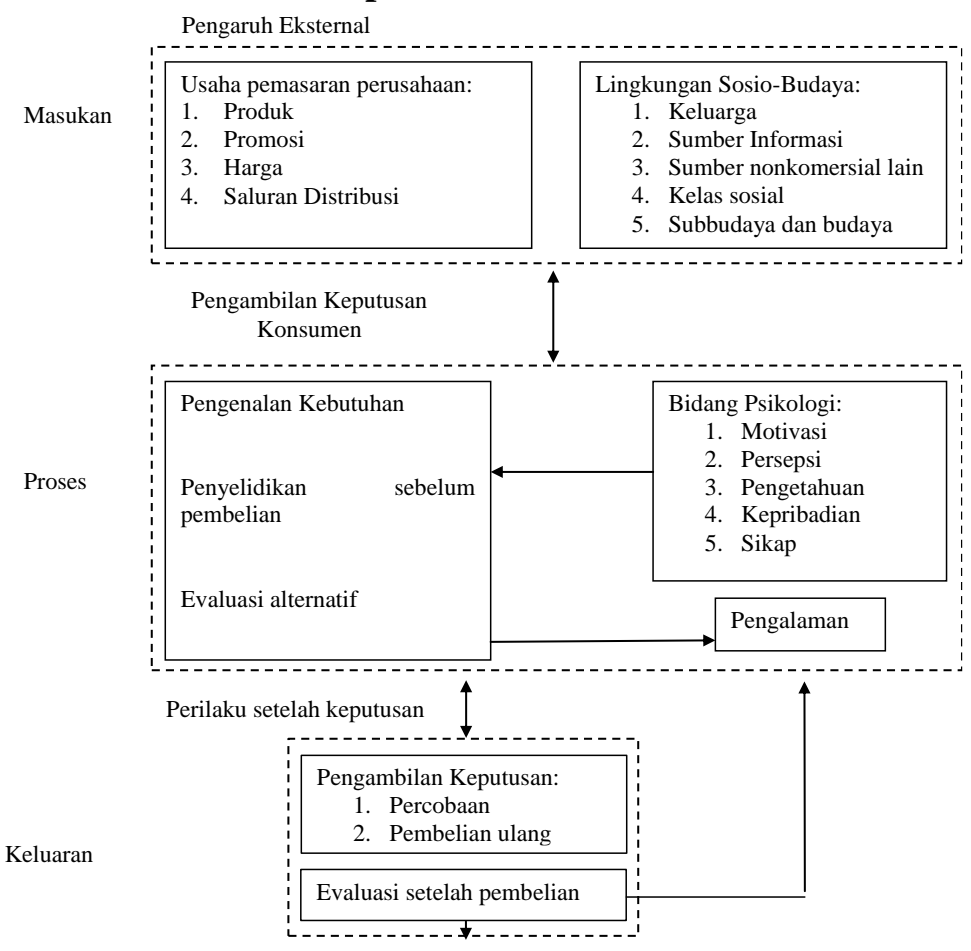

Sumber: Schiffman and Kanuk (2008: 8)

a. Tahap Masukan (Input)

Pada tahap masukan mempengaruhi pengenalan konsumen terhadap kebutuhan atas produk dan terdiri dari dua sumber informasi utama yang pertama adalah usaha pemasaran yang dilakukan oleh perusahaan (produk, harga, promosi, dan tempat), kemudian yang kedua adalah pengaruh sosiologis eksternal atas konsumen (keluarga, teman-teman, tetangga, sumber informal, dan nonkomersial lain, kelas sosial, serta keanggotaan budaya dan subbudaya).

b. Tahap Proses 
Pada tahap ini memfokuskan pada bagaimana cara konsumen dalam mengambil keputusan, yang dipengaruhi oleh faktor psikologis (motivasi, persepsi, pengetahuan, kepribadian, dan sikap) kemudian pada tahap masukan mempengaruhi pengenalan konsumen terhadap kebutuhannya, mencari informasi sebelum melakukan pembelian, dan evaluasi terhadap berbagai alternatif produk. Pengalaman yang diperoleh dari evaluasi berbagai alternatif, akan mempengaruhi sifat psikologis para konsumen.

\section{c. Tahap Keluaran (Output)}

Tahap keluaran dalam model pengambilan keputusan konsumen terdapat dua macam kegiatan yang berhubungan erat setelah konsumen melakukan proses pengambilan keputusan, yaitu: perilaku pembelian dan evaluasi setelah melakukan pembelian. Konsumen mencoba untuk membeli produk baru, jika dirinya merasa cocok atau puas dengan pembeliannya tersebut maka konsumen akan melakukan pembelian ulang terhadap produk tersebut.

\section{EWOM}

Menurut Kotler dan Keller (2012: 512) word of mouth adalah pemasaran yang dilakukan oleh orang baik dalam bentuk lisan, tertulis, atau komunikasi elektronik yang berhubungan dengan kebaikan pengalaman membeli atau menggunakan produk dan jasa, juga merupakan salah satu bentuk bauran komunikasi yang tentu saja diharapkan dapat mengkomunikasikan sesuatu kepada konsumen lainnya. Schiffman dan Kanuk (2010) mendefinisikan eWOM sebagai word of mouth yang dilakukan secara online.
Thorson dan Rodgers (2006: 40) mendefinisikan eWOM sebagai pernyataan positif atau negatif yang dibuat tentang suatu produk, perusahaan, atau kepribadian media yang dibuat tersedia secara luas melalui internet. Sementara itu Kietzmann dan Canhoto (2013: 39) menyatakan eWOM sebagai pernyataan apa pun yang didasarkan pada pengalaman positif, netral, atau negatif yang dibuat oleh calon, pelanggan aktual, atau mantan konsumen tentang produk, layanan, merek, atau perusahaan untuk banyak orang dan lembaga melalui Internet (melalui situs web, jejaring sosial, instant messenger, feed berita, dll).

Hasan (2010: 184$)$
mengemukakan alasan yang
membuat WOM/eWOM, dapat
menjadi informasi yang kuat dalam
mempengaruhi keputusan pembelian,
yaitu:

a) WOM/eWOM adalah sumber informasi yang independen dan jujur, yang artinya ketika informasi datang dari seorang teman itu lebih kredibel karena tidak ada keterkaitan dari orang tersebut dengan perusahaan produk tersebut.

b) WOM/eWOM sangat kuat karena memberikan manfaat kepada yang bertanya dengan pengalaman langsung tentang produk melalui pengalaman teman.

c) WOM/eWOM disesuaikan dengan orang-orang yang tertarik di dalamnya. Seseorang tidak akan bergabung dengan percakapan, kecuali jika mereka tertarik pada topik yang disukainya.

d) WOM/eWOM menghasilkan informasi media informal. 
e) WOM/eWOM dapat mulai dari satu sumber tergantung bagaimana kekuatan influencer dan jaringan sosial itu menyebar dengan cepat dan secara luas kepada orang lain.

f) WOM/eWOM tidak dibatasi oleh ruang atau kendala lainnya, seperti ikatan sosial, waktu, keluarga atau hambatan fisik lainnya.

\section{Kerangka Penelitian}

Berdasarkan pemaparan tentang keputusan pembelian, maka penting bagi perusahaan untuk memahami tentang proses keputusan pembelian tersebut. Salah satunya adalah bagaimana seorang konsumen mencari informasi tentang produk, hingga mereka menentukan keputusan pembelian. Adapun langkah yang bisa dilakukan oleh perusahaan adalah dengan memanfaatkan electronic word of mouth (eWOM) dalam menyampaikan produk unggulan kafe-kafe yang ada di Kota Pekanbaru. Pemasaran viral atau disebut juga dengan istilah electronic word of mouth (eWOM) menurut Kotler (2012: 139) adalah pemasaran menggunakan internet untuk menciptakan efek berita dari mulut ke mulut untuk mendukung usaha dan tujuan pemasaran. Pemasaran viral menular seperti virus adalah bentuk lain berita dari mulut ke mulut atau berita dari satu klik mouse ke klik berikutnya, yang mendorong konsumen menceritakan produk dan jasa yang dikembangkan perusahaan dalam bentuk audio, video, dan tulisan kepada orang lain.

EWOM bukan merupakan komunikasi yang murni interpersonal karena dapat diakses oleh banyak orang, tetapi bukan juga sepenuhnya komunikasi massa karena hanya ditujukan kepada orang tertentu secara spesifik. Schiffman dan Kanuk (2010: 182) mendefinisikan eWOM sebagai word of mouth yang dilakukan secara online.

Penerapan eWOM melalui Instagram ini tentu saja berkaitan dengan pengalaman yang diceritakan oleh konsumen yang telah melakukan konsumsi suatu produk. Hasan (2010: 185) mengemukakan alasan yang membuat WOM dapat menjadi informasi yang kuat dalam mempengaruhi keputusan pembelian, yaitu WOM sangat kuat karena memberikan manfaat kepada yang bertanya dengan pengalaman langsung tentang produk melalui pengalaman teman.

\section{Gambar 5: Kerangka Penelitian}

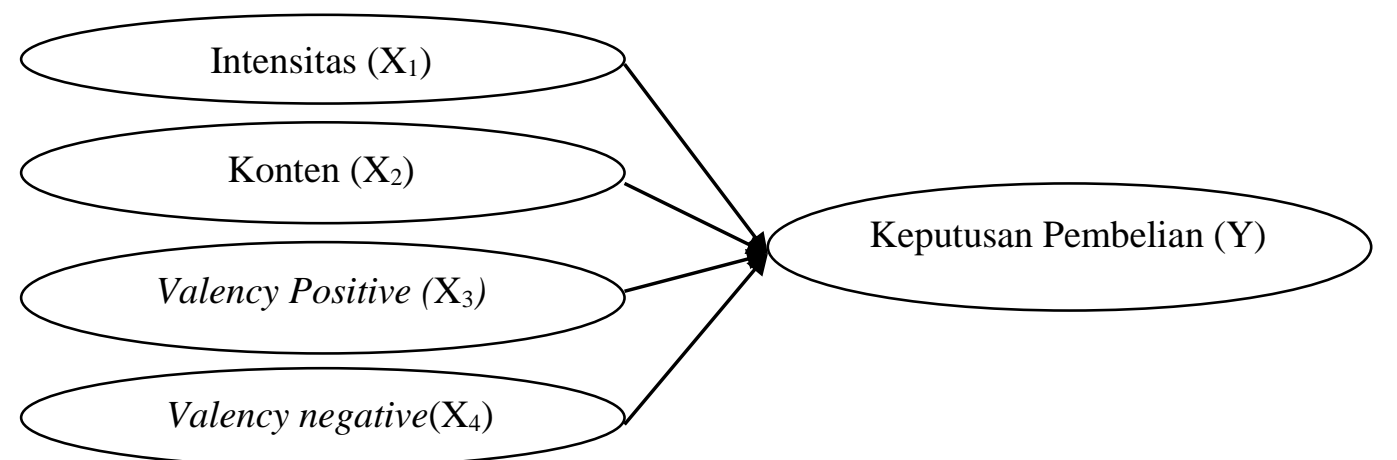

Sumber: Hasan (2010:185); Kotler (2012:139); Kotler dan Amstrong (2008:179). 


\section{Hipotesis}

Berdasarkan kerangka pemikiran, maka beberapa hipotesis untuk penelitian ini dipaparkan sebagai berikut:

1. Terdapat pengaruh intensitas terhadap keputusan pembelian.

2. Terdapat pengaruh konten terhadap keputusan pembelian.

3. Terdapat pengaruh valency positive terhadap keputusan pembelian.

4. Terdapat pengaruh valency negative terhadap keputusan pembelian.

\section{METODE PENELITIAN}

\section{Lokasi dan Waktu Penelitian}

Penelitian ini dilaksanakan pada kafe-kafe yang ada di Kota Pekanbaru. Waktu pengumpulan data pada penelitian ini adalah dari bulan Juni 2019 hingga selesai.

\section{Jenis dan Sumber Data}

Jenis data yang digunakan pada penelitian ini adalah data kuantitatif, yaitu data informasi yang berupa simbol angka atau bilangan berdasarkan simbol-simbol angka tersebut, perhitungan secara kuantitatif dapat dilakukan untuk menghasilkan suatu kesimpulan yang berlaku umum didalam suatu parameter dan sangat mudah dilakukan (Sugiono, 2014: 12).

\section{Populasi dan Sampel}

Populasi dalam penelitian ini adalah pengunjung dari kafe yang menjadi objek penelitian yang ada di Kota Pekanbaru, terutama untuk kafe-kafe yang tidak berada di jalan pratokol. Kafe yang tidak berada di jalan pratokol ini tentu saja membutuhkan sarana promosi untuk menyampaikan informasi tentang kafe tersebut kepada masyarakat, terutama Instagram.

Teknik penarikan sampel yang akan digunakan adalah judgmental sampling. Judgmental sampling adalah teknik dimana peneliti menilai apakah seseorang yang ditemui di lapangan termasuk dalam kriteria sampel dan layak mengisi kuesioner serta bersedia mengisi kuesioner akan langsung menjadi responden. Roscoe dalam Sugiyono (2005: 102) menyatakan ukuran sampel yang layak dalam penelitan adalah $30-500$ responden. Maka, sampel pada penelitian ini adalah sebanyak 110 orang.

Metode sampel menggunakan metode sampling area, digunakan untuk menentukan bila objek yang akan diteliti atau sumber data sangat luas, maka pengambilan sampelnya berdasarkan daerah populasi yang telah ditetapkan. Untuk setiap kafe jumlah responden yang digunakan adalah lebih kurang 9 orang. Penentuan sampel 9 orang per lokasi (kafe) maka digunakan judgment sampling. Penggunaan sampling dilakukan dengan mendatangi konsumen kafe-kafe yang dijadikan lokasi penelitian di Kota Pekanbaru

\section{Teknik Pengumpulan Data}

Metode pengumpulan data yang digunakan penulis dalam penelitian ini yaitu dengan menggunakan kuesioner. Yaitu suatu alat pengumpulan data yang digunakan oleh penulis dalam penelitian untuk mendapatkan informasi yang dibutuhkan dari sampel dengan membuat suatu daftar pertanyaan yang berupa lembaran angket atau kuesioner yang diajukan dan diisi oleh para responden yang 
telah ditentukan sebelumnya dan akan diolah oleh penulis untuk disajikan dalam bentuk tabulasi. Dalam kuesioner ini digunakan skala ordinal yang terdiri dari sangat setuju, setuju, netral, tidak setuju dan sangat tidak setuju..

\section{Teknik Analisa Data}

Data diperoleh dari hasil penyebaran kuesioner dalam bentuk tabel kemudian menghubungkannya dengan teori-teori yang relevan dengan penelitian ini. Selanjutnya penulis menarik kesimpulan. Untuk menganalisis data secara kuantitatif maka penulis akan menggunakan teknik analisis data secara statistik menggunakan SPSS versi 23.00.
Dalam pengambilan keputusan interprestasi mean deskriptif dari masing-masing variabel yang diteliti.

\section{IV.HASIL PENELITIAN \& PEMBAHASAN \\ Hasil Penelitian \\ Pengujian Asumsi Data \\ Uji Validitas dan Reliabilitas \\ Uji Validitas (Validity) Kuesioner}

Pada program statistical product and service solution (SPSS) teknik pengujian yang digunakan validitas adalah dengan menggunakan korelasi. Dalam penelitian ini untuk mengetahui valid suatu variabel dilakukan pengujian dengan menggunakan teknik validity analysis.

Tabel 1: Uji Validitas

\begin{tabular}{|c|c|c|c|c|c|}
\hline Variabel & Pernyataan & $\mathrm{N}$ & $\begin{array}{c}\mathrm{r} \\
\text { hitung }\end{array}$ & $\mathrm{r}$ tabel & Keputusan \\
\hline \multirow{3}{*}{ Intensitas } & Int.1 & 110 & 0.907 & 0.257 & Valid \\
\cline { 2 - 6 } & Int.2 & 110 & 0.907 & 0.257 & Valid \\
\cline { 2 - 6 } & Int.3 & 110 & 0.658 & 0.257 & Valid \\
\hline \multirow{4}{*}{ Konten } & Kont.1 & 110 & 0.707 & 0.257 & Valid \\
\cline { 2 - 6 } & Kont.2 & 110 & 0.799 & 0.257 & Valid \\
\cline { 2 - 6 } & Kont.3 & 110 & 0.459 & 0.257 & Valid \\
\cline { 2 - 6 } & Kont.4 & 110 & 0.866 & 0.257 & Valid \\
\hline \multirow{6}{*}{ Valency Positif } & Valf.1 & 110 & 0.646 & 0.257 & Valid \\
\cline { 2 - 6 } & Valf.2 & 110 & 0.740 & 0.257 & Valid \\
\hline Valency Negatif & Valn.1 & 110 & 0.716 & 0.257 & Valid \\
\cline { 2 - 6 } & Valn.2 & 110 & 0.567 & 0.257 & Valid \\
\hline Keputusan Pembelian & Kep.1 & 110 & 0.830 & 0.257 & Valid \\
\cline { 2 - 6 } & Kep.2 & 110 & 0.785 & 0.257 & Valid \\
\cline { 2 - 6 } & Kep.3 & 110 & 0.653 & 0.257 & Valid \\
\cline { 2 - 6 } & Kep.4 & 110 & 0.381 & 0.257 & Valid \\
\hline \multicolumn{2}{|c|}{ Valid N (listwise) } & & & 110 & \\
\hline
\end{tabular}

Sumber: Data Olahan, 2019

Berdasarkan perhitungan nilai korelasi person dari setiap item pernyataan dalam setiap variabel, maka dapat dilihat bahwa setelah dilakukan uji validitas semua item masing-masing variabel (intensitas, konten,valency positive, valency negative, dan keputusan pembelian), maka hasilnya $\mathrm{r}$ hitung > $\mathrm{r}$ tabel (df: $105=0.257)$. Dengan demikian 
dapat disimpulkan bahwa semua item masing-masing variabel memenuhi syarat untuk valid.

\section{Uji Reliabilitas (reliability )}

Dalam pengujian ini batasan nilai adalah 0,6 . Jika nilai reliabilitas kurang dari 0,6 maka nilainya kurang baik. Nilai reliabilitas dalam uji ini adalah pada kolom reliabilitiy statistics (cronbach's alpha). Dan diketahui nilai reliabilitas ke lima variabel berada diatas angka 0,6. Artinya adalah bahwa alat ukur yang digunakan dalam penelitian ini reliable atau dapat dipercaya. Berikut ini adalah hasil uji reliability.

Tabel 2: Uji Reliability

\begin{tabular}{|c|l|c|c|c|}
\hline No & \multicolumn{1}{|c|}{ Variabel } & $\begin{array}{c}\text { Jumlah Item dalam } \\
\text { Kuesioner }\end{array}$ & $\begin{array}{c}\text { Cronbach's } \\
\text { Alpha }\end{array}$ & Keputusan \\
\hline 1 & Intensitas $\left(\mathrm{X}_{1}\right)$ & 3 & 0.793 & Reliabel \\
\hline 2 & Konten $\left(\mathrm{X}_{2}\right)$ & 4 & 0.707 & Reliabel \\
\hline 3 & Valency positif $\left(\mathrm{X}_{3}\right)$ & 2 & 0.822 & Reliabel \\
\hline 4 & Valency Negatif $\left(\mathrm{X}_{4}\right)$ & 2 & 0.667 & Reliabel \\
\hline 5 & Keputusan Pembelian $(\mathrm{Y})$ & 4 & 0.745 & Reliabel \\
\hline
\end{tabular}

Pada hasil perhitungan terhadap nilai cronbach's alpha, maka dapat dilihat bahwa nilai cronbach's alpha masing-masing variabel adalah sebagai berikut: Intensitas(X1) (0.793), Konten (X2) (0.707), Valency positive (X3) (822), Valency Negative (X4) (0.667), dan Keputusan Pembelian (0.745). Dengan demikian dapat dikatakan bahwa semua variabel tersebut adalah reliable, karena memilki nilai Cronbach's Alpha di atas 0,60.

\section{Uji Normalitas Data}

Untuk mendeteksi normalitas, maka dapat dilihat dengan menggunakan grafik normal P-P plot of regression standarized residual. Pada gambar terlihat titik-titik menyebar di sekitar garis diagonal, serta penyebarannya mengikuti arah garis diagonal, maka model regresi memenuhi asumsi normalitas. 


\section{Normal P-P Plot of Regression Standardized} Residual

\section{Dependent Variable: Kep.Pembelian}

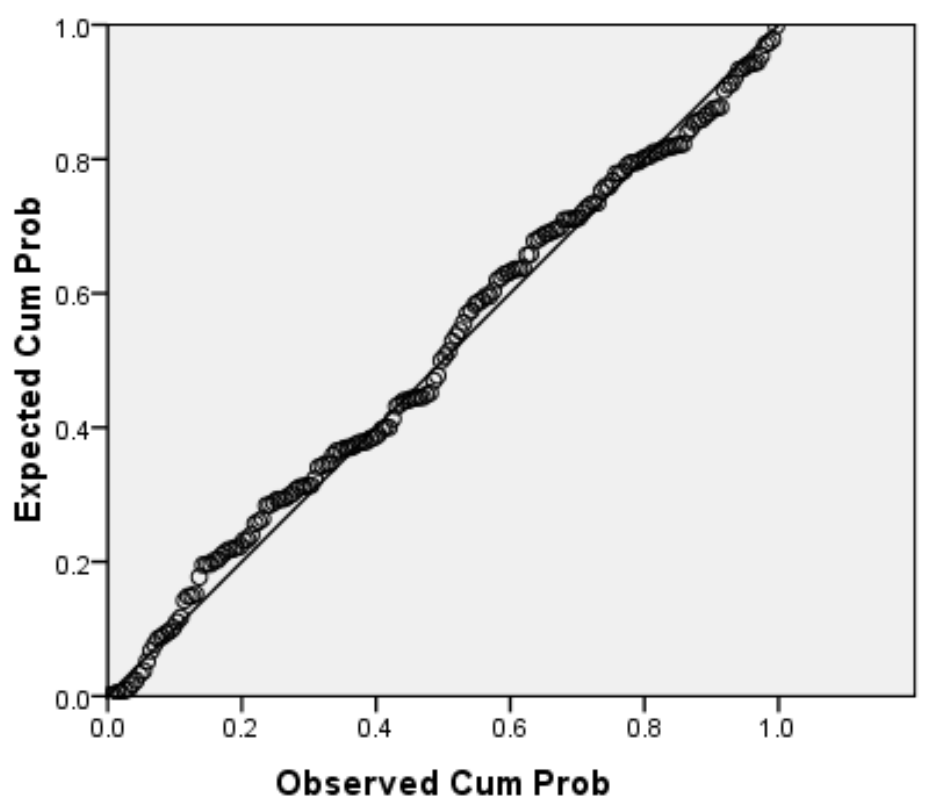

Sumber: Data Olahan, 2019

Uji normalitas adalah langkah awal yang harus dilakukan untuk setiap analisis multiviate khususnya jika tujuannya adalah inferensi. Jika terdapat normalitas, maka residual akan teritribusi secara normal. Setelah melihat gambar hasil dari

\section{PEMBAHASAN}

Pengaruh intensitas terhadap keputusan pembelian

Berdasarkan pada hasil penelitian, maka dapat disimpulkan bahwa intensitas berpengaruh positif dan signifikan terhadap keputusan pembelian. Artinya setiap peningkatan dan perbaikan terhadap intensitas, maka akan meningkatkan keputusan pembelian konsumen.

Intensitas dalam electronic word of mouth (eWOM) adalah pengolahan data dengan menggunakan SPSS versi 23.00 maka dapat dikatakan bahwa semua residual yang ada dalam penelitian ini terdisitribusi secara normal.

banyaknya pendapat atau opini yang ditulis oleh konsumen dalam sebuah situs jejaring sosial. frekuensi seseorang untuk mengakses jejaring sosial, guna mendapatkan informasi tentang tempat-tempat nongkrong (kafe) masih perlu untuk diperhatikan. Semakin sering seorang konsumen mengakses informasi tentang suatu produk, maka akan semakin kuat dalam ingatannya untuk mengkonsumsi suatu produk.

Hal ini menunjukkan bahwa intensitas ataupun keseringan 
penayangan iklan melalui media sosial, dan dilihat oleh konsumen akan menciptakan suatu perasaan atau pengalaman yang menyenangkan dan rasa ingin tahu terhadap kesenangan yang ditampilkan pada media sosial tersebut. Hal ini lah nantinya yang akan menarik konsumen untuk berkunjung dan makan di kafe yang diteliti. Semakin sering pengguna media sosial melihat informasi tentang suatu produk makanan dan minuman, maka mereka akan semakin ingin untuk berkunjung dan menikmati makanan dan minuman, sebagaimana yang ditampilkan pada media sosial kafe-kafe yang diteliti.

\section{Pengaruh konten terhadap keputusan pembelian. \\ Berdasarkan pada hasil} penelitian, maka dapat disimpulkan bahwa konten berpengaruh positif dan signifikan terhadap keputusan pembelian. Artinya semakin banyak tampilan yang berisi informasi tentang makanan yang disajikan pada suatu kafe, maka akan meningkatkan keputusan pembelian konsumen di kafe tersebut bahkan pada orangorang yang belum pernah datang ke kafe tersebut.

Berdasarkan rata-rata tanggapan responden terhadap indikator variabel konten termasuk pada kategori baik. Adapun indikator yang masih berada dibawah rata-rata variabel konten adalah Informasi tentang variasi produk yang dijual. Hal ini menunjukkan bahwa informasi yang disampaikan oleh jejaring sosial, khususnya Instagram pada beberapa kafe yang ada di Kota Pekanbaru tidak menjelaskan secara detail tentang detail produk yang dijual. Detail produk yang dijual tersebut berkaitan dengan rasa, bahan baku, dan juga tampilan dari makan dan minuman yang ditawarkan kepada konsumen. Selanjutnya adalah kondisi ini menunjukkan bahwa informasi tentang harga produk yang dijual oleh kafe masih belum lengkap, sehingga ketertarikan konsumen untuk membeli belum terlalu baik, karena harga merupakan salah satu faktor yang menentukan seseorang membeli atau tidak suatu produk, khususnya produk makanan dan minuman pada kafe di Kota Pekanbaru.

\section{Pengaruh valency positive terhadap keputusan pembelian.}

Hasil penelitian menunjukkan

bahwa Berdasarkan pada hasil penelitian, maka dapat disimpulkan bahwa pendapat positif berpengaruh positif dan signifikan terhadap keputusan pembelian. Artinya setiap peningkatan dan perbaikan terhadap pendapat positif, maka akan meningkatkan keputusan pembelian konsumen.

Berdasarkan rata-rata tanggapan responden terhadap indikator variabel valency positive termasuk pada kategori baik. Adapun indikator yang masih berada dibawah rata-rata variabel valency positive adalah rekomendasi dari pengguna media sosial. Rekomendasi merupakan pengaruh sangat penting dalam sebuah informasi. Seorang konsumen akan cenderung mendengarkan atau membaca rekomendasi dari konsumen lainnya, terutama rekomendasi dari konsumen yang dikenal. Oleh karena itu, dalam media sosial, khususnya Instagram, rata-rata orang yang saling mengenali, sehingga rekomendasi sangat penting dalam menentukan keputusan orang membeli atau tidaknya. Jika rekomendasi positif 
yang diterimanya, maka mereka akan cenderung untuk membeli suatu produk.

\section{Pengaruh valency negative terhadap keputusan pembelian.}

Berdasarkan pada hasil penelitian, maka dapat disimpulkan bahwa pendapat negatif berpengaruh negatif dan signifikan terhadap keputusan pembelian. Artinya semakin banyak keluhan konsumen atas pelayanan maupun makanan yang disajikan pada suatu kafe, maka akan menurun keputusan pembelian konsumen di kafe tersebut.

$$
\text { Berdasarkan hasil }
$$
perhitungan tanggapan responden terhadap indikator variabel valency negative maka dapat disimpulkan bahwa rata-rata responden menyetujui bahwa apabila ada yang tidak puas dari kafe akan menceritakan di Instagram kafe tersebut. Hal ini menunjukan bahwa apabila ada keluhan atas pelayanan dan makanan yang ada di kafe mereka akan menyampaikanya lewat media Instagram kafe yang mereka kunjungi, meskipun ada beberapa responden yang tidak menyetujui hal tersebut. Begitu juga dengan menyampaikan komentar negatif tentang produk makanan dan minuman yang ditawarkan kafe melalui Instagram apabila tidak sesuai dengan promosi yang dilakukan. Meskipun ada beberapa responden yang tidak menyetujui hal tersebut.

\section{SIMPULAN DAN SARAN Simpulan}

1. Intensitas berpengaruh positif dan signifikan terhadap keputusan pembelian. Artinya setiap peningkatan dan perbaikan terhadap intensitas, maka akan meningkatkan keputusan pembelian konsumen terhadap suatu produk.

2. Konten berpengaruh positif dan signifikan terhadap keputusan pembelian. Artinya setiap peningkatan dan perbaikan terhadap konten, maka akan meningkatkan keputusan pembelian konsumen terhadap suatu produk.

3. Valency positive berpengaruh positif dan signifikan terhadap keputusan pembelian. Artinya semakin banyak komentar positif konsumen atas pelayanan maupun makanan dan minuman yang disajikan pada sebuah kafe, maka akan meningkatkan keputusan pembelian konsumen di kafe tersebut bahkan pada orangorang yang belum pernah datang ke kafe tersebut.

4. Valency negative berpengaruh negatif dan signifikan terhadap keputusan pembelian. Artinya semakin banyak komentas negatif atau keluhan konsumen atas pelayanan maupun makanan dan minuman yang disajikan pada suatu kafe, maka keputusan pembelian konsumen di kafe tersebut akan menurun.

\section{Saran}

Berdasarkan kesimpulan di atas, maka dapat diberikan beberapa saran sebagai berikut:

1. Intensitas 


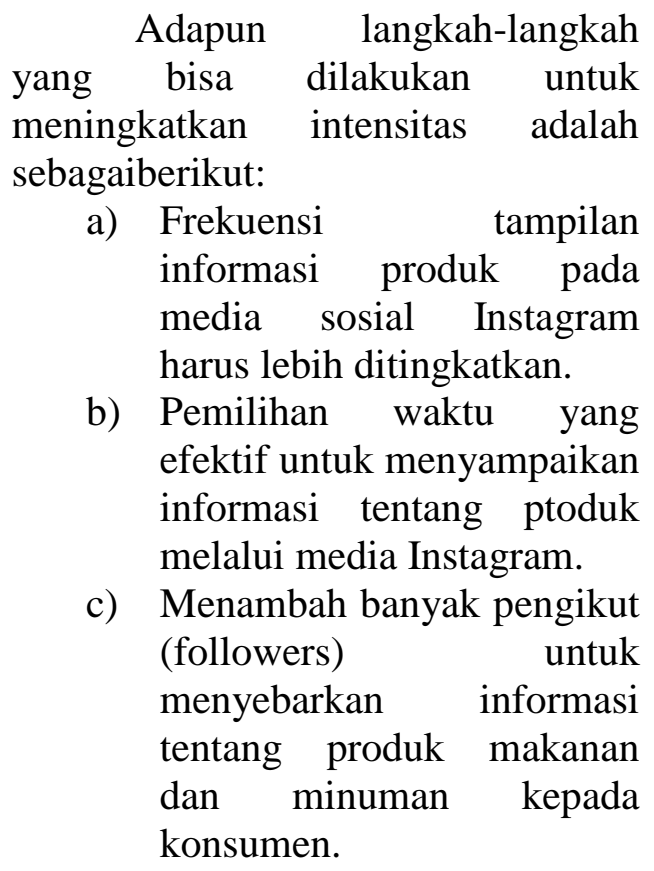

2. Konten

Adapun langkah-langkah yang bias dilakukan untuk meningkatkan konten adalah sebagai berikut:

a) Konten yang ditampilkan pada media social harusmenarik untuk konsumen.

b) Informasi tentang kualitas produk harus disampaikan kepada konsumen melalui tampilan konten iklan di Instagram.

c) Informasi harga harus ditampilkan pada media Instagram tersebut.

3. Valency Positive

Adapun langkah-langkah yang bias dilakukan untuk meningkatkan valency positive adalah sebagai berikut:

a) Admin Instagram harus mampu untuk mengelompokkan informasi yang positif tentang produk makanan dan minuman pada media social Instagram.

b) Selalu membalas setiap komentar positif dari konsumen, dengan ucapanucapan yang menyenangkan, seperti "terimakasih".

4. Valency Negative

Adapun langkah-langkah

yang bias dilakukan untuk mengurangi valency negative adalah sebagai berikut:

a) Admin Instagram harus mampu untuk mengelompokkan informasi yang negatif tentang produk makanan dan minuman pada media social Instagram.

b) Selalu membalas setiap komentar negatif dari konsumen, dengan ucapanucapan yang menyenangkan, seperti "mohon maaf", "nanti kami perbaiki" dan lain-lain.

\section{DAFTAR PUSTAKA}

Badan Pusat Statistik Kota Pekanbaru, Kota Pekanbaru Dalam Angka 2018.

Hasan Ali, 2013, MarketingDan Kasus-Kasus Pilihan, Yogyakarta: Center for Academic Publishing Service. Kietzmann, J. dan Canhoto, A., 2013,

"Bittersweet!Understanding and managing electronic word of mouth", Journal of Public Affairs, 13(2), hal.146-159.

Kottler, Philip \& Keller, Kevin Lane. (2007).Manajemen

Pemasaran, edisi 12 jilid 2. Jakarta: Indeks.

Kotler, Amstrong, 2009, PrinsipPrinsip Pemasaran, edisi 12 jilid 1. Jakarta: Penerbit Erlangga. 
Schiffman, L. G., Kanuk, L. L. 2008.

Perilaku Konsumen Edisi

Ketujuh. Jakarta:PT. Indeks

Group Media.

Schiffman dan Kanuk., 2010,

Perilaku Konsumen, Edisi

Kedua, Jakarta: PT. Indeks

Gramedia.

Sugiyono, 2013, Statistika untuk

Penelitian, Alfabeta, Bandung 